\title{
LCLR FILTER DESIGN AND MODELLING FOR HARMONIC MITIGATION IN INTERCONNECTED MICRO GRID SYSTEM
}

\author{
D. S. Sargar ${ }^{1}$, C. L. Bhattar ${ }^{2}$ \\ ${ }^{1}$ P.G. Scholar, Department of Electrical Engineering, Rajarambapu Institute of Technology, Maharashtra, India \\ ${ }^{2}$ Assistant Professor, Department of Electrical Engineering, Rajarambapu Institute of Technology, Maharashtra, \\ India
}

\begin{abstract}
Today many people are attracted towards distribution generation (DG) because of low energy cost power supply, local generation, highly reliable system, supply with good power quality. Increasing attention and investment in renewable energy that is DG energy sources give rise to rapid development of high penetration renewable energy sources like solar energy, wind energy, hydro energy. Out of this most important and best is the solar energy. There are multiple ways to interface PV arrays with the power grid, but in there is problem of power quality. Today's important concern of the power system is the power quality in case of renewable energy sources. The power quality improvement in the interconnected micro grid systems and grid interconnection with Distribution Generation (DGs) is the challenging task and to overcome the power quality problem passive filters are the best and cost effective solution. In this paper the LCLR filter is implemented between inverter and grid. The complete system consists of photovoltaic cell (PV), DC-DC boost converter, DC-AC inverter, LCLR filter and the grid. This paper also consists of complete MATLAB simulation of $P V$ cell, DC-DC boost converter and inverter with LCLR filter.
\end{abstract}

Key Words: Renewable energy, PV module, DC-DC boost converter, DGs, LCLR filter, power quality, micro grid (MG) and THD

\section{INTRODUCTION}

Nowadays the cost of fuel increased due to increasing demand of fuel and use of it, but the fuels are exhaustible in nature so in the future they will be completely vanished in one day. Other reasons are the tremendous increase in population and global warming. The best solution for to reduce the fuel cost and reduce unlimited use of fuel and to save the fuel for future is the use of renewable energy sources for the generation of electrical energy. Some best renewable energy sources for generation of electricity are: (1) Wind energy (2) solar energy (3) Tidal energy (4) Hydro energy [1]. The distribution generation (DGs) means the use of renewable energy sources for generation of electricity and electricity generation is local and own generation. In these the solar energy and wind energy sources are the very popular energy sources because of its availability and suitability. That is in the distribution system electrical energy is generated using wind mill, solar panel with DCDC converter and DC-AC converter i.e. inverter with its suitable controlling system [1]. The main objectives of use renewable energy sources are: i) provide low cost energy with local generation ii) Reduce the cost of conventional energy sources. iii) Provide good quality power supply. The power quality is obtained using the various power quality improvement devices and equipment's like DSTATCOM (distribution static compensation), DVR (dynamic voltage restorer), filters (active and passive), and zigzag transformers, etc. For the grid interconnection of renewable energy sources with power grid or micro grid is done using inductor in past cases [2] and in recently $L C L$ (Inductor $(L)$ Capacitor $(C)$ - Inductor $(L))$ filters are used [2]-[5].

The higher order harmonic attenuation of $L C L$ filter allows the use of lower order switching frequencies to find the harmonic limitations and these harmonic constraints are defined by IEEE standards. IEEE 1233 standard is for power quality definitions [6]. IEEE 519 standard is for harmonic control in electrical power system [7]. The higher-order $L C L R$ filter has been used in place of the traditional single $L$ i.e. only one inductor in series with line for getting the ripple free the output currents at output of the inverter which is formed by using IGBTs or MOSFETs as power electronic devices. The LCLR filter achieves the higher harmonic reduction along with simple design, the overall weight and size of the $L C L R$ filter is reduced due to appropriate design and modelling. In addition $L C L R$ filter does not produce very high voltage drop across it. $L C L R$ filters have been used in between inverters connected with renewable energy sources with pulse width modulation techniques (PWM) for inverters.

In this paper detailed description about $L C L R$ filter modeling, designing procedure is given. The objective of this paper is to carry out the detailed study about modeling and designing of $L C L R$ filter for inverter with renewable energy sources as solar (PV panel). The MATLAB simulation of PV model with boost converter and full bridge inverter with $L C L R$ filter is done with MATLAB Simulink software. The proposed block diagram is shown in fig-1. 


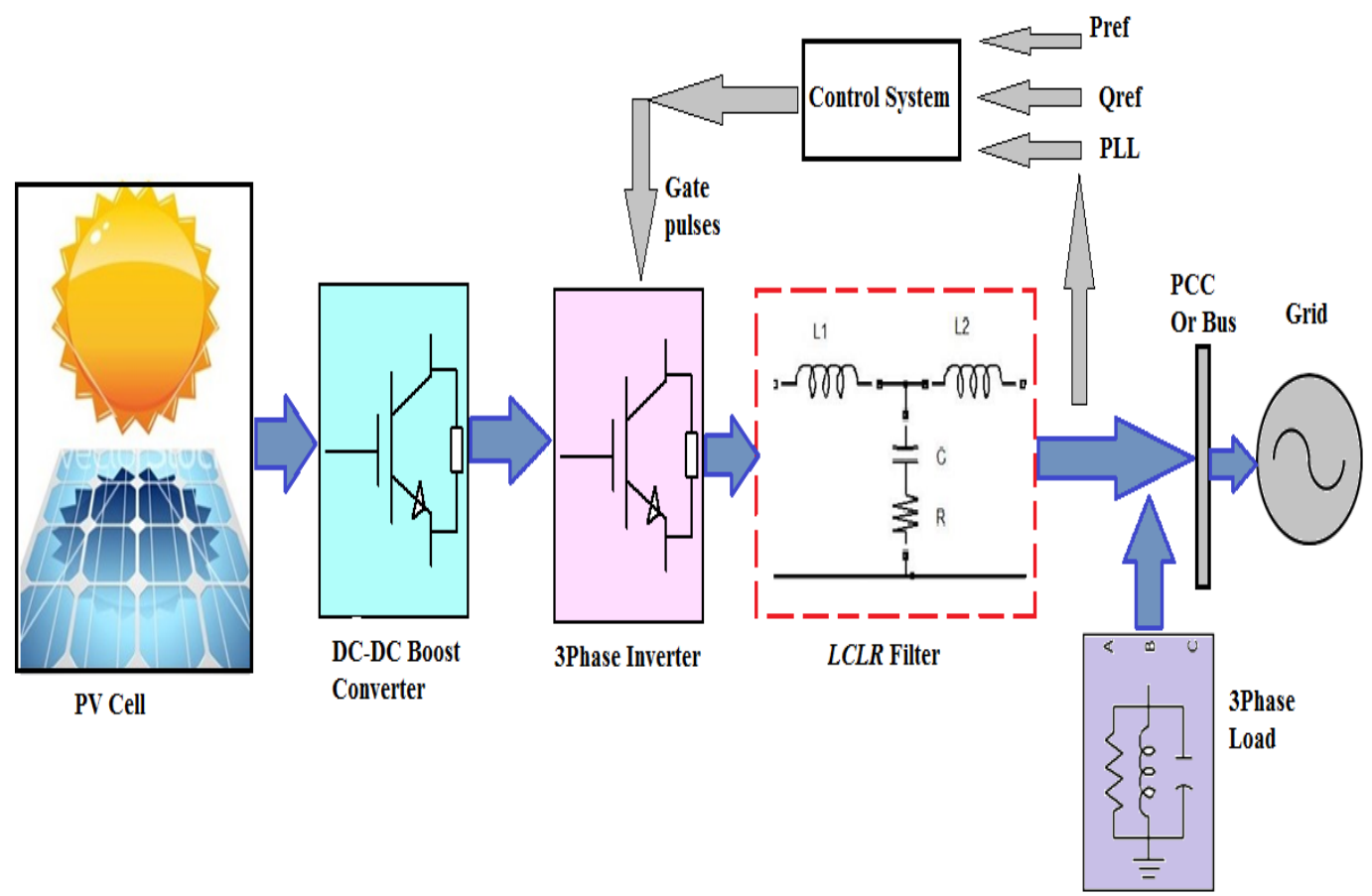

Fig-1: Proposed Block Diagram of Inverter with $L C L R$ Filter

\section{PV MODULE AND BOOST CONVERTER}

\subsection{PV Module (Photovoltaic Cell)}

PV solar energy is a best, clean, renewable energy with a long service life and high reliability. But because of its high cost, energy contribution is not as much of as other energy sources. It is therefore important to have effective and flexible models. In the photovoltaic (PV) system the solar energy is converted into electrical energy using semiconductor device to generate the charge. Two parameters are very important in the PV systems that are temperature $\left(\mathrm{T}\right.$ in $\left.{ }^{\circ} \mathrm{C}\right)$ and solar irradiation is nothing but the light intensity which is in watt per meter square; $\mathrm{W} / \mathrm{m}^{2}$. The equivalent electrical circuit of PV cell is shown in fig-2, which consists of semiconductor diode $\mathrm{D}$, series resistance $\left(R_{s}\right)$, shunt resistance is $\left(R_{s h}\right)$, current flowing through diode $\left(I_{d}\right)$ and $I_{s c}$ is short circuit current and $I$ is the current of PV

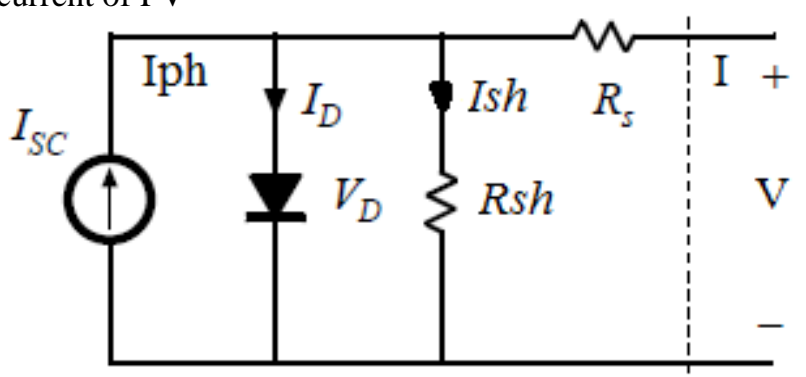

Fig -2: PV cell Equivalent Electrical Circuit.

Under the standard conditions solar radiation $1000 \mathrm{~W} / \mathrm{m}^{2}$ and temperature $25^{\circ} \mathrm{C}$ is considered [8].

By applying Kirchhoff's Current Law (KCL) to circuit which is given by,

$$
I=I_{p h}-I_{d}-I_{s h}
$$

Now, the shunt current is given by equation

$$
I_{p h}=I_{r} \cdot \frac{I_{s c}}{I_{r 0}}
$$

The diode current $I_{d}$ and the diode characteristics is given by

$$
I_{d}=I_{s} \cdot\left(e^{\frac{\left(V+I . R_{s}\right)}{n \cdot V_{t} \cdot N_{s}}}-1\right)
$$

The shunt current is given by,

$$
I_{s h}=\frac{\left(V+I . R_{s}\right)}{R_{p}}
$$

The equation of thermal voltage is given by

$$
V_{t}=\frac{K . T}{q}
$$

Where, $\mathrm{K}$ is Boltzmann constant, $\mathrm{T}$ is temperature and $q$ is the charge [16].

The output voltage of the PV cell is depends upon the number cells connected in series with each other. Adding cells in series will increase the voltage. In the proposed 
system single cell PV gives output voltage 21.07V DC and by increasing seven series cells then output voltage become $147.49 \mathrm{~V}$ DC. The PV module model is done in the MATLAB Simulink Soft wares with considering table-1 parameters. The PV curve and IV curve are shown in fig-3 and fig-4 respectively $[17,18]$.

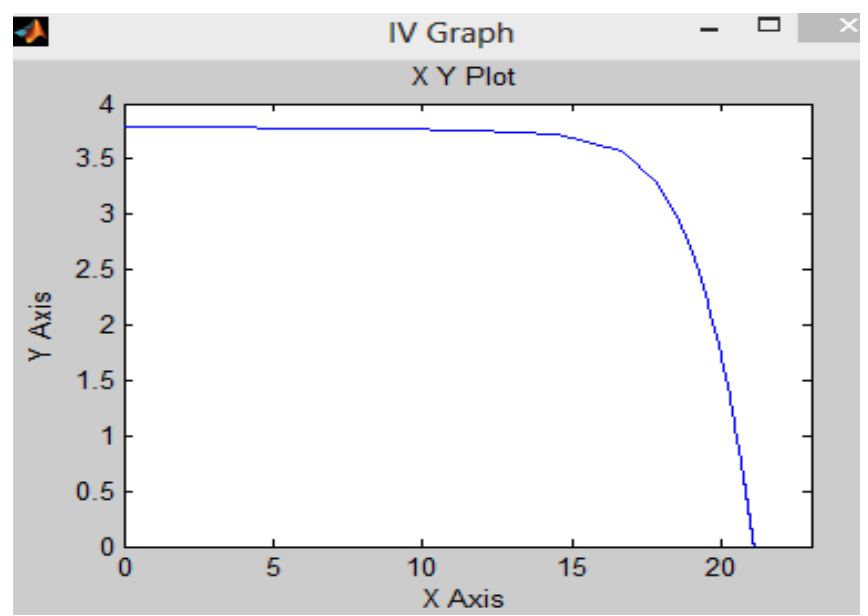

Fig -3: IV curve of PV cell

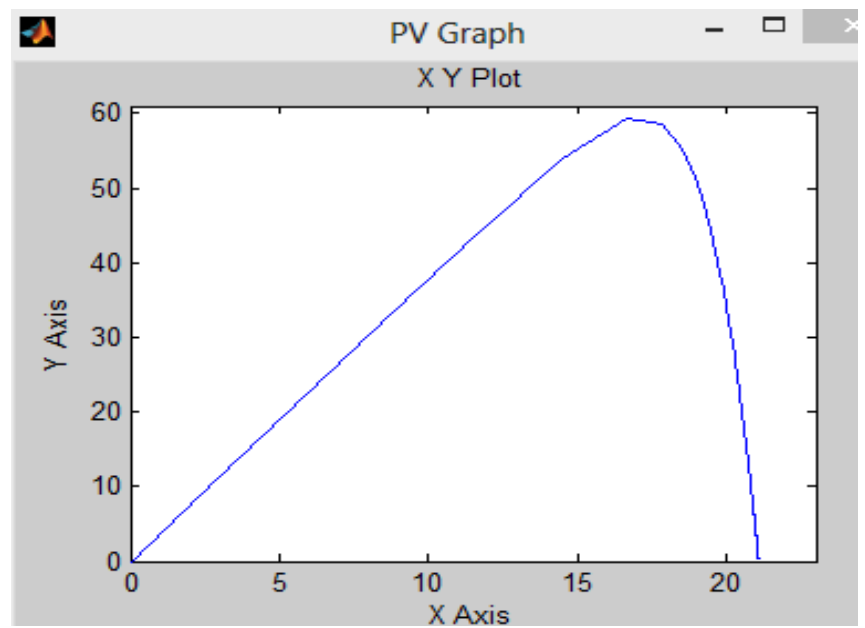

Fig -4: PV curve of PV cell

The single PV cell output voltage output voltage which is $21.07 \mathrm{~V}$ DC shown in fig-5 and seven cell PV output voltage is shown in fig-6 which is near about 147.49V DC.

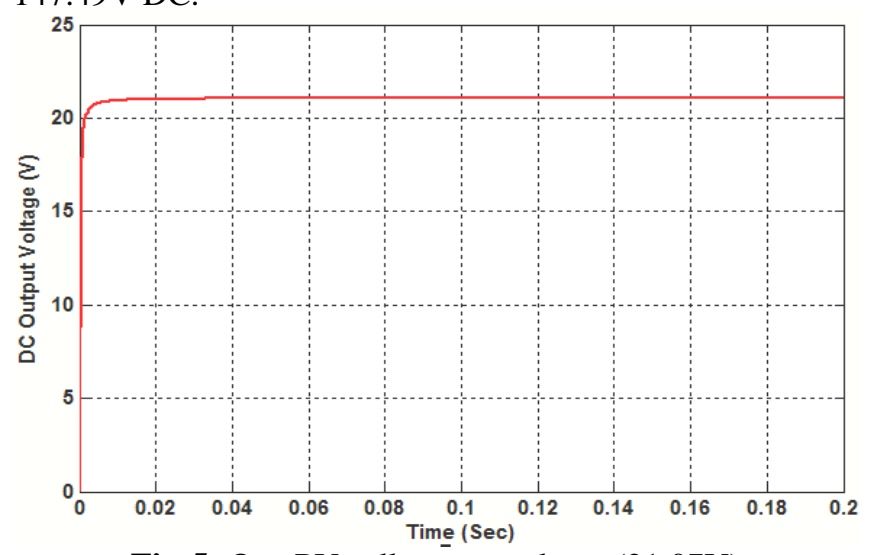

Fig-5: One PV cell output voltage (21.07V)

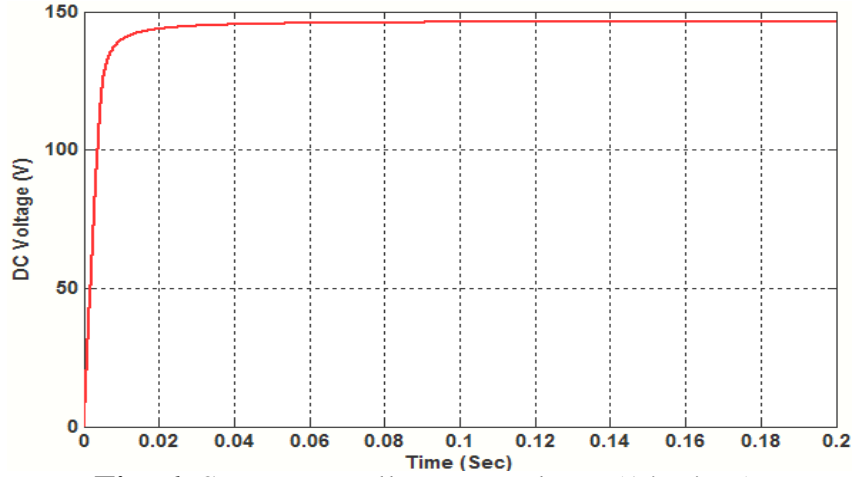

Fig -6: Seven PV cell output voltage (147.49V).

\subsection{DC-DC Boost Converter}

DC-DC Boost converters are used to convert DC nonuniform voltage from the PV cell to required fixed high level regulated or uniform DC voltage. In addition the boost converter boosts the voltage level from low to high. The boost converter circuit consists of input DC voltage from PV cell, Inductor (L_boost) for boosting, IGBT with pulse generator for getting the suitable control output, diode, capacitor $\left(C \_\right.$boost $)$and load resistance $R$ [9]. In this paper seven PV cells produces $147.49 \mathrm{~V}$ DC, but using this $147.49 \mathrm{~V}$ boost converter boost the DC voltage up to $312 \mathrm{~V}$ DC. The parameters of DC-DC boost converter are calculated using following equations-

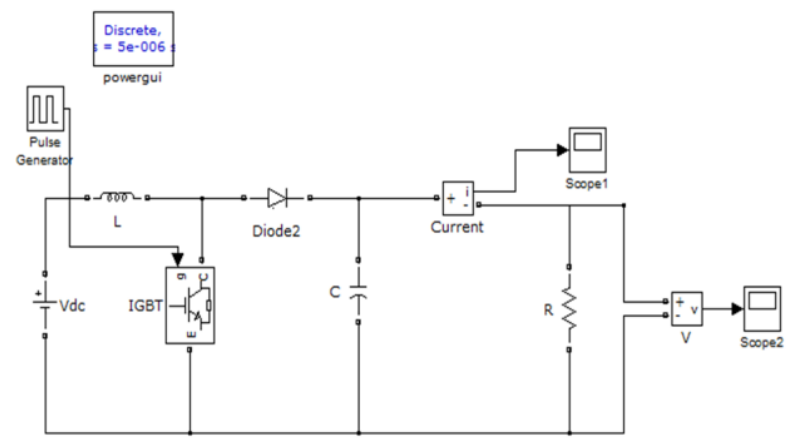

Fig-7:Simulation model of DC-DC boost converter

(a) Duty Cycle: Duty cycle $(D)$ of the boost converter is intended by considering converter efficiency $(\eta)$ 95\%, for the more sensible results of the duty cycle efficiency is added in duty cycle [10]. Mathematical expression for duty cycle is given by,

$$
D=\frac{V_{\text {in }}}{V_{\text {out }}} \times \eta
$$

(b) Inductor Selection: To finding good inductor value equation (7) is used, $d i$ is the ripple current [11]

$$
L_{\text {boost }}=\frac{V_{\text {in }}\left(V_{\text {out }}-V_{\text {in }}\right)}{d i \times f_{s} \times V_{\text {out }}} ; \mathrm{mH} \quad d i=2 I \frac{\text { Vin }}{\text { Vout }}
$$

(c) Capacitor Selection: To select best capacitor value equation (8) is used. [11-12] 


$$
C_{\text {boost }}=\frac{I \times D}{f_{s} \times d V} \quad \mathrm{~F}
$$

Where,

$d V$ is the ripple voltage

$$
d V=\frac{I}{(1-D)}+\frac{d I}{2}
$$

(d) Resistance Selection: The resistance value is calculating using following equation,

$$
R=\frac{V_{\text {out }}}{I_{\text {out }}}
$$

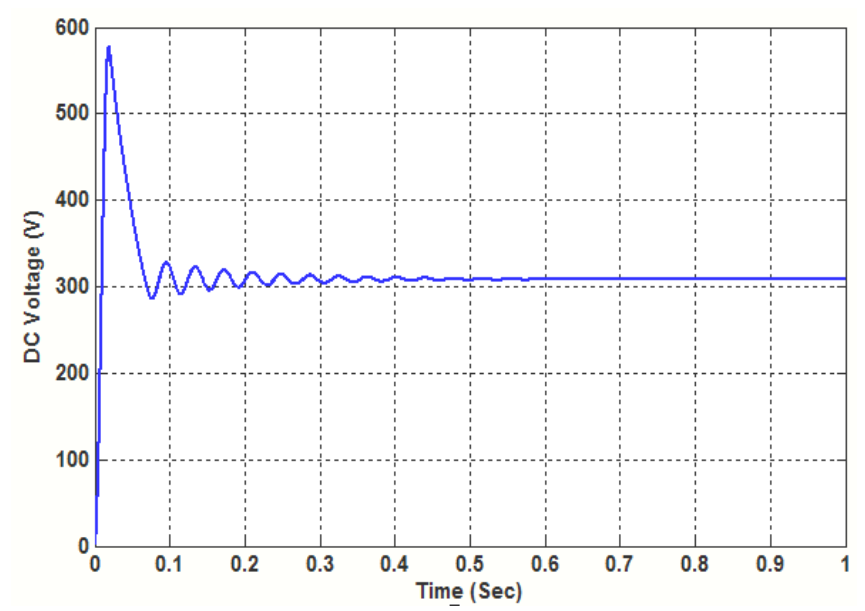

Fig-8: DC-DC Boost Converter Output Voltage (312V DC)

\section{LCLR FILTER MODELLING}

A. Per Phase Equivalent Circuit Modelling of LCLR Filter The per phase equivalent model of $L C L R$ filter is fully described in case of its modeling and designing. Fig-9 shows the per phase model of $L C L R$ filter. $L, C, L$ and $R$ are the important parameters, $L_{1}$ is the inverter side inductor, $L_{2}$ is the grid side inductor, $C$ is the capacitor and $R$ is the damping resistance. The capacitor $C$ is connected in series with resistance $R$.

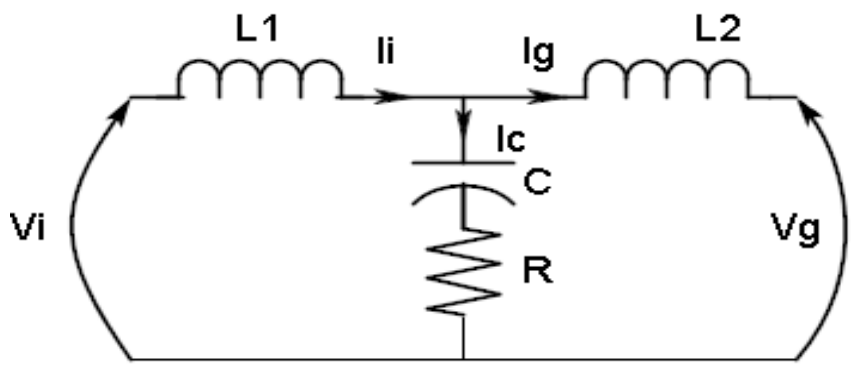

Fig-9: Per Phase Model of LCLR Filter

The resistance $\mathrm{R}$ is connected to avoid the damping in the circuit. $V_{i}$ is the inverter side voltage i.e. output voltage of the inverter, $V_{g}$ is the grid side voltage, $I_{i}$ is the inverter output current, $I_{c}$ is the current flowing through capacitor and $I_{g}$ is the grid current.

The three phase model of the $L C L R$ is shown in the fig- 10 .

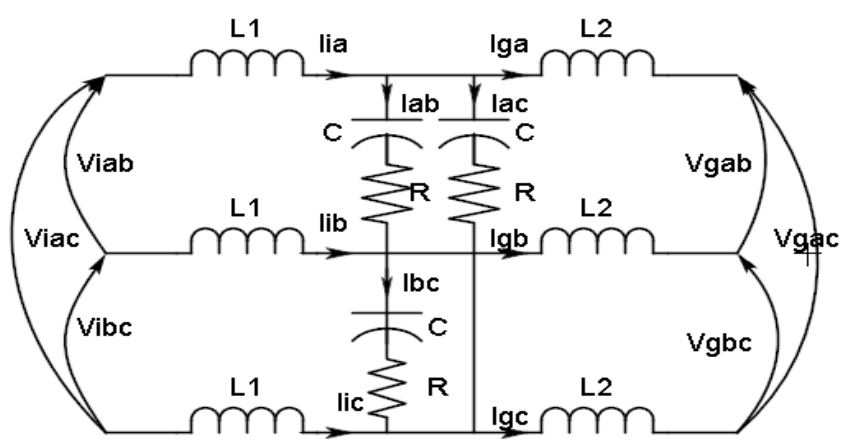

Fig-10: Three phase model of $L C L R$ Filter.

Transfer function of $L C L R$ filter i.e. transfer function of $L C L R$ filter with damping resistance

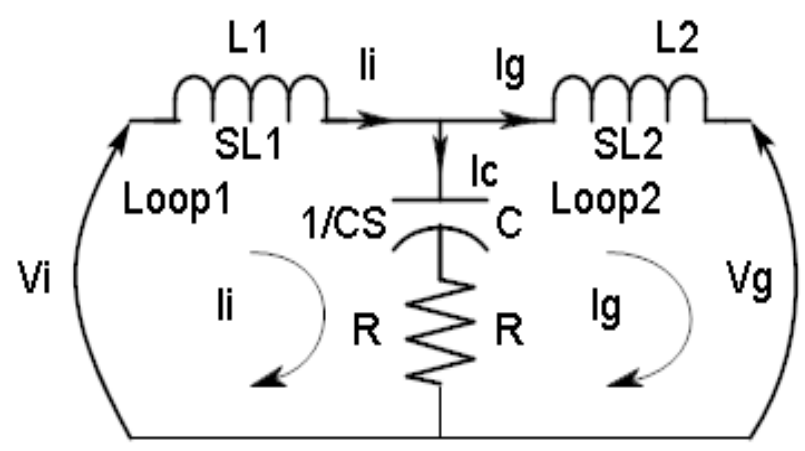

Fig-11: Per Phase model of LCLR filter for finding TF

By applying Kirchhoff's Voltage Law to loop1 we get equation,

$$
V i-L 1 S I i-\frac{1}{C S}(I i-I g)-R(I i-I g)=\mathrm{O}(10)
$$

By applying Kirchhoff's Voltage Law to loop2 we get equation,

$$
V g-R(I g-I i)-\frac{1}{C S}(I g-I i)-L 2 S I g=0
$$

$V g=0$ because grid voltage assumed to be ultimate so to dumping out all harmonic frequencies we set the $V g=0$

$$
\begin{aligned}
& -R I g+R I i-\frac{I g}{C S}+\frac{I i}{C S}-L 2 S I g=0 \\
& -\left(R+\frac{1}{C S}+L 2 S\right) I g+\left(R+\frac{1}{C S}\right) I i=0
\end{aligned}
$$

By some manipulation we get $I i$ i.e. inverter side current

$$
I i=\left(\frac{R C S+L 2 C S^{2}+1}{R C S+1}\right) I g
$$

From equation (10) 


$$
\begin{aligned}
& V i-L 1 S I i-\frac{I i}{C S}+\frac{I g}{C S}-R I i+R I g=0 \\
& V i=\left(L 1 S+\frac{1}{S C}+R\right) I i-\left(\frac{1}{S C}+R\right) I g
\end{aligned}
$$

Putting value of Ii from equation (14) in the equation (16)

$V i=\frac{\left(L 1 C S^{2}+R C S+1\right)}{C S} \frac{\left(L 2 C S^{2} R C S+1\right)}{(R C S+1)} I g-\frac{(R C S+1)}{C S} I g$

By solving brackets we get,

$$
\begin{aligned}
& V i=\frac{\left[L 1 L 2 C^{2} S^{4}+L 1 R C^{2} S^{3}+L 1 C S^{2}+L 2 R C^{2} S^{3}+R^{2} C^{2} S^{2}+R C S+L 2 C S^{2}+R C S+1\right]}{C S(R C S+1)} I g \\
& -\frac{(R C S+1)}{C S} I g
\end{aligned}
$$

By taking denominator as $C S$

$V i(R C S+1)=\frac{\left[L 1 L 2 C^{2} S^{4}+L 1 R C^{2} S^{3}+L 1 C S^{2}+L 2 R C^{2} S^{3}+R^{2} C^{2} S^{2}+R C S+L 2 C S^{2}+R C S+1\right]}{C S} I g$ $-\frac{(R C S+1)^{2}}{C S} I g$

Now by cancelling plus and minus terms we get,

$$
\frac{V i(R C S+1)}{I g}=\frac{L 1 L 2 C S^{3}+(L 1+L 2) R C S^{2}+(L 1+L 2) S}{1}
$$

Now by rearranging terms we get important transfer function

$$
\frac{I g}{V i}=\frac{S C R+1}{S^{3} C L 1 L 2+S^{2} C R(L 1+L 2)+S(L 1+L 2)}
$$

$$
H_{L C L R}(S)=\frac{I g}{V i}=\frac{S C R+1}{S^{3} C L 1 L 2+S^{2} C R(L 1+L 2)+S(L 1+L 2)}
$$

\section{B. Frequency Response of LCLR filter}

To know the frequency response of the LCLR filter system essentials to find transfer function of the filter. The transfer function of the $L C L R$ which is the compensation characteristics of the filter and given by $H_{L C L R}=\frac{I_{g}}{V_{i}}$, where $I_{g}$ is the grid current and $V_{i}$ inverter output voltage, in this case grid side voltage is assumed to be an idyllic voltage. Equation (23) gives the transfer function of LCLR with damping resistance. [12]

$$
H_{L C L R}(S)=\frac{C R S+1}{L_{1} C L_{2} S^{3}+C R\left(L_{1}+L_{2}\right) S^{2}+\left(L_{1}+L_{2}\right) S}
$$

The filter parameter values are achieved from filter design procedure which is shown in table-2. Response of filter is shown in the Bode plot of $L C L R$ with damping resistance in fig-12

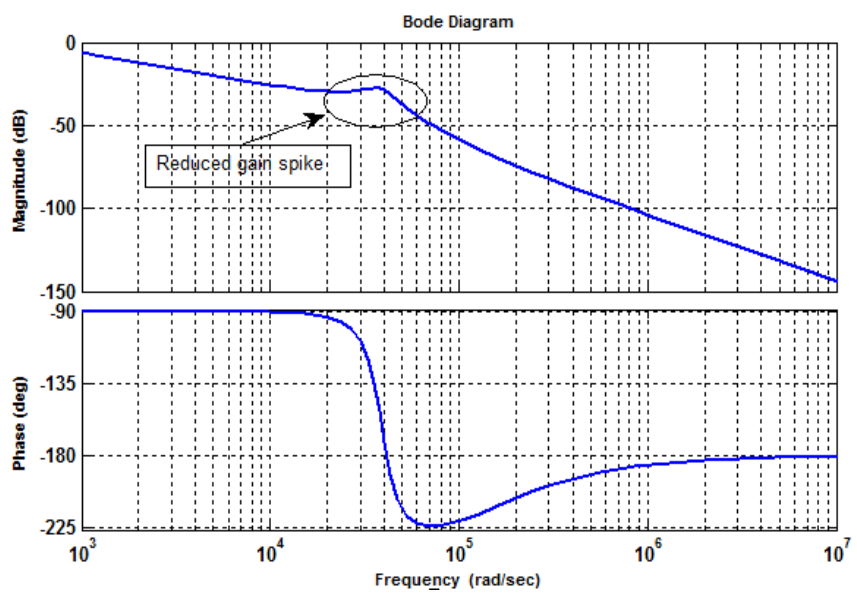

Fig-12: Bode plots of the LCLR filter showing response of filter with damping resistance.

The insertion of resistance in series with capacitor affects the frequency response of the $L C L R$ filter which is easily observed in the fig-12. Without series resistance very high gain spikes are present in the magnitude Bode plot. When series resistance with capacitor inserted in filter then gain spike in the magnitude plot is almost reduced which smoothing the overall current response, in addition the series resistance plays important role in the filter to damp out the oscillations and its value is very small so very less voltage drop will occurs.

\section{FILTER DESIGN PROCEDURE}

\section{A. Methodical Filter Design}

Some important characteristics of filters must be considered in the designing of $L C L R$ filter, such characteristics are: (i) filter size (ii) filter design (iii) amount of current ripple (iv) cost of the filter ( $\mathrm{v}$ ) switching attenuation performance of the filter. In case of the only $L C L$ filter there is chance of resonance due to the reactive power requirement and because of this capacitor of filter will interfere with grid resistance; therefore must add passive component as like resistor in series with the capacitor. The passive componentresistance is added in series with capacitor to smooth the current ripples. The active components can be used to solve these problems.

The important parameters required for the filter design are:

$V_{p h}$ : Phase voltage of inverter output

$V_{L L}:$ Line to line voltage of inverter output

$P$ : Rated active power

$V_{D C}$ : DC voltage from renewable energy sources i.e. input voltage to the inverter

$f_{s w}$ : Switching frequency of the inverter

$f_{g}$ : Grid frequency

$\omega_{g}:$ Grid angular frequency 
$f_{\text {res }}:$ Resonance frequency

$m:$ Inverter modulation factor

$k_{a}$ : Desired attenuation constant

Firstly need to find base values of the system so that filter values is in percentage of base values, the base capacitance $\left(C_{b}\right)$ and base impedance $\left(Z_{b}\right)$ which are given by,

$$
\begin{aligned}
Z_{b} & =\frac{E_{n}^{2}}{P} \\
C_{b} & =\frac{1}{\omega_{g} Z_{b}} \quad ; \quad \omega_{g}=2 \pi f_{g}
\end{aligned}
$$

In the normal power system, it is supposed that highest variation of power factor in grid is $5 \%$, when this value multiplied by base capacitance value to get capacitance value i.e. $C=0.05 C_{b}$. The design factor greater than $5 \%$ can used to compensate the reactance of the filter which is inductive reactance [13]. The highest ripple of the current at output of the inverter is given by

$$
\Delta I_{L \max }=\frac{2 V_{D C}}{3 L_{1}}(1-m) m T_{s w}
$$

$T_{s w}$ : Is the switching time of the inverter and $m$ : modulation factor depends upon which PWM technique used by the inverter. It is seen that highest peak to peak current distortion occurs at $m=0.5$, therefore inductor maximum current given by

$$
\Delta I_{L \max }=\frac{V_{D C}}{6 f_{s w} L_{1}}
$$

Where, $L_{1}$ is the inductor of inverter side. For the maximum rated current consider $10 \%$ ripple in current. Rated maximum current given by,

$$
\Delta I_{L \max }=0.1 I_{\max }
$$

Where

$$
I_{\max }=\frac{P \sqrt{2}}{3 V_{p h}}
$$

Therefore $L_{1}$ is given by,

$$
L_{1}=\frac{V_{D C}}{0.6 f_{s w} I_{\max }}
$$

The $L C L R$ filter minimizes current distortion to very low level so ripple value will be below $2 \%$. The relation between harmonic current of inverter and the grid is given by,

$$
\frac{i_{g}(h)}{i_{i}(h)}=\frac{1}{\left|1+r\left(1-L_{1} C_{b} \omega_{s w}^{2} x\right)\right|}=k_{a}
$$

Where $k_{a}$ is the desired attenuation factor of the inverter and $r$ is the constant which is ratio of grid side inductor $\left(L_{2}\right)$ to the inverter side inductor $\left(L_{1}\right)$ and equation (32) gives its relation.

$$
L_{2}=r L_{1}
$$

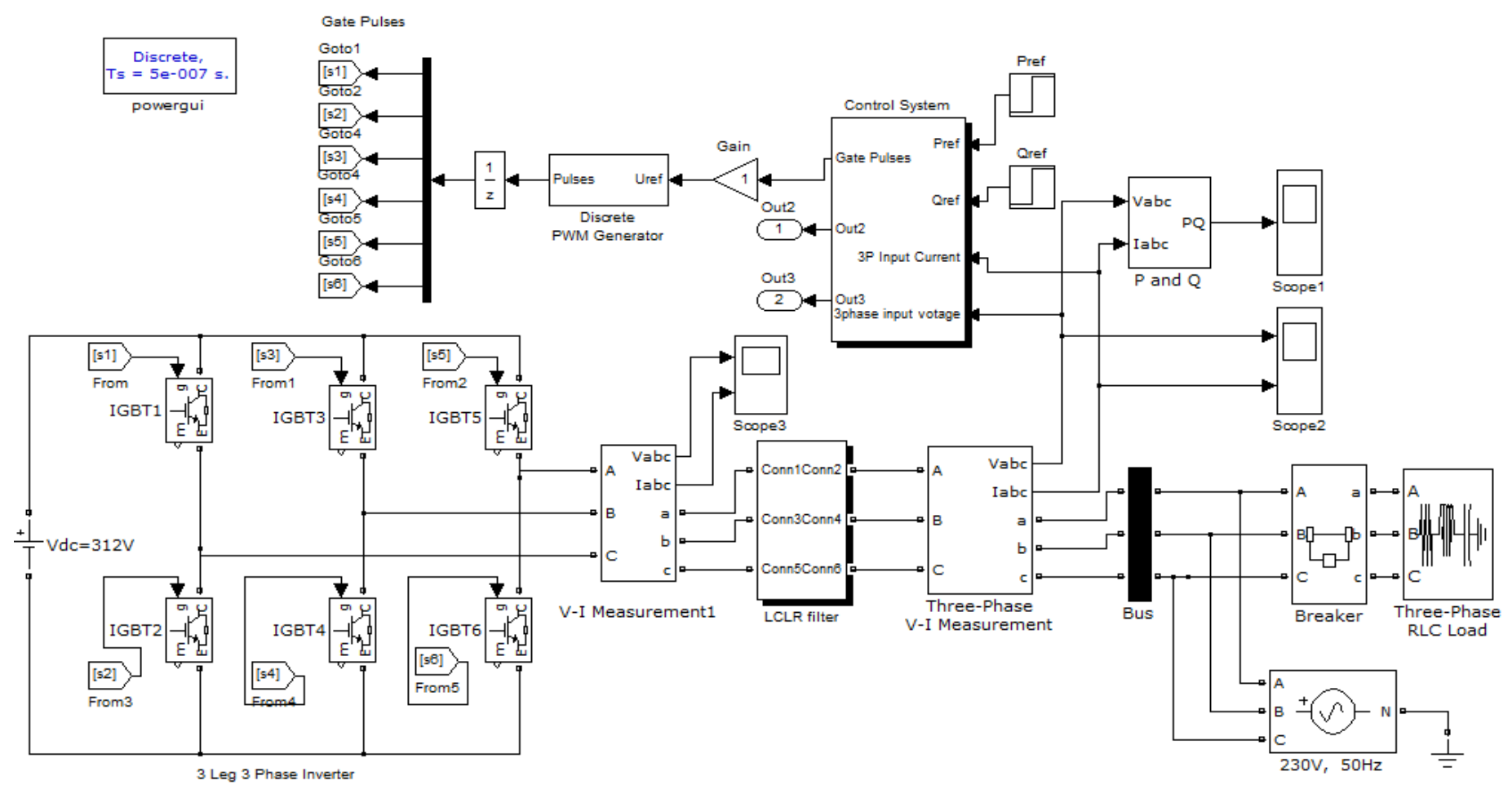

Fig-13: Implemented System of Inverter with $L C L R$ filter. 
The scheming for the various values of $r$ any can assess transfer of filter at specific resonance frequency which depends on the nominal impedance of the grid. [14]

The value of grid side inductor in terms of desired attenuation factor is given by,

$$
L_{2}=\frac{\sqrt{\frac{1}{k_{a}^{2}}}+1}{C \omega_{s w}^{2}}
$$

The resistance $(R)$ in series with capacitor $(C)$ compensates the part of ripples in the switching frequency to avoid the resonance of the $L C L R$ filter. The resonance frequencies in terms of $L C L R$ filter parameters given in,

$$
\omega_{\text {res }}=\sqrt{\frac{L_{1}+L_{2}}{L_{1} L_{2} C}}
$$

The range of resonance frequency should satisfy

$$
10 f_{g}<f_{\text {res }}<0.5 f_{\text {sw }}
$$

The resistance value should be one third of capacitor impedance at the resonance frequency [15]. The equation (36) gives the value of resistance of $L C L R$ filter.

$$
R=\frac{1}{3 \omega_{r e s} C}
$$

Table-1: PV Cell Parameters

\begin{tabular}{|l|c|c|}
\hline \multicolumn{1}{|c|}{ PARAMETER } & SYMBOLS & VALUE \\
\hline Temperature & $T$ & $25+273.15^{0} \mathrm{C}$ \\
\hline Irradiance (p. u.) & $G=I r r$ & $1 \mathrm{~W} / \mathrm{m}^{2}$ \\
\hline Nominal Irradiance & $I r 0$ & $1000 \mathrm{~W} / \mathrm{m}^{2}$ \\
\hline Boltzmann Constant & $K$ & $1.38 \mathrm{e}-3$ \\
\hline Charge & $q$ & $1.6 \mathrm{e}-19 \mathrm{C}$ \\
\hline Emission coefficient & $n$ & 1.36 \\
\hline Open circuit voltage & Voc & $21.3 \mathrm{~V}$ \\
\hline Short circuit current & Isc & $3.8 \mathrm{~A}$ \\
\hline
\end{tabular}

Table-2: DC-DC Boost Converter Parameters

\begin{tabular}{|l|l|l|}
\hline PARAMETERS & SYMBOLS & VALUE \\
\hline Duty Cycle & $D$ & 0.575962 \\
\hline Boost Inductor & L_boost & $0.0019 \mathrm{H}$ \\
\hline Boost Capacitor & C_boost & $0.0044 \mathrm{~F}$ \\
\hline Load Resistance & $R$ & $16.4211 \Omega$ \\
\hline
\end{tabular}

Table-3: System Parameters

\begin{tabular}{|l|l|l|}
\hline PARAMETERS & SYMBOLS & VALUE \\
\hline Phase Grid Voltage & $V g$ & $230 \mathrm{~V}$ \\
\hline DC Link Voltage & $V_{D C}$ & $312 \mathrm{~V}$ \\
\hline Nominal Power & $P$ & $5 \mathrm{KW}$ \\
\hline
\end{tabular}

\begin{tabular}{|l|l|l|}
\hline Grid Frequency & $f_{g}$ & $50 \mathrm{~Hz}$ \\
\hline Switching Frequency & $f_{s w}$ & $15 \mathrm{KHz}$ \\
\hline Modulation Factor & $M$ & 0.05 \\
\hline Attenuation Factor & $K_{a}$ & 0.2 \\
\hline
\end{tabular}

Table-4: LCLR Filter Parameters

\begin{tabular}{|l|l|l|}
\hline PARAMETERS & SYMBOLS & VALUE \\
\hline Inverter Side Inductor & $L_{1}$ & $1.9729 \mathrm{mH}$ \\
\hline Grid Side Inductor & $L_{2}$ & $0.04495 \mathrm{mH}$ \\
\hline Capacitor of Filter & $C$ & $15.043 \mu \mathrm{F}$ \\
\hline Damping Resistance & $R$ & $0.5694 \Omega$ \\
\hline
\end{tabular}

\section{SIMULATION RESULTS AND DISCUSSION}

\section{A. Inverter controller and LCLR Filter}

The model of Inverter with $L C L R$ is done using MATLAB in Simulink Power System Tool Box shown in fig.13. The $L C L R$ filter plays very important role in the Power Quality Improvement and better interconnection of renewable energy sources inverter with grid. For the inverter $d q o$ algorithm is used for the power quality improvement which reduces THD to very low level. $d q o$ Means the directquadrature-zero transformation is mathematical transformation which rotates the reference frame of three phase systems. The $d q o$ transformation decreases three AC quantities (phases a, b, c) to two DC quantities so that simplified calculations can be done with DC quantities. These are done to simplify the calculations for control of the any three phase inverters.

\section{B. Inverter Without LCLR Filter}

Without LCLR filter inverter output current contains harmonics. The Fig-14 shows the inverter output voltage $(230 \mathrm{~V})$ and fig-15(a), (b) and (c) shows phase a, b and c currents respectively and fig-16 shows inverter output current of combined phases a, b and c (0.015A). THD of the system is very high which is up to $50.38 \%$. In this case current is much distorted so in the power system it is very dangerous and harmful. The Fig-17 shows THD analysis of the current.

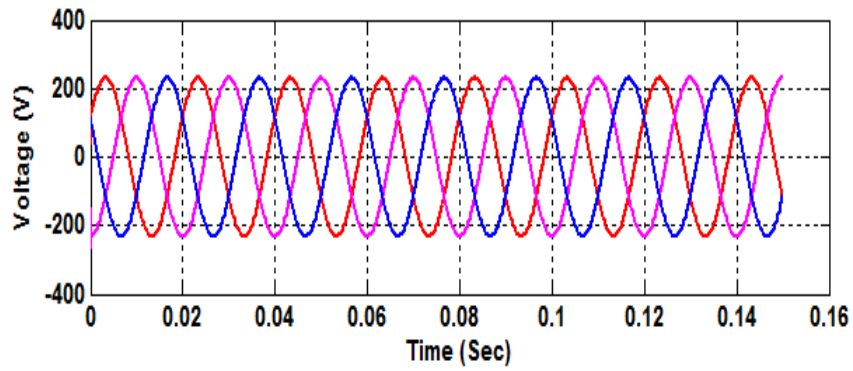

Fig-14: Inverter output voltage without LCLR Filter (230V) 

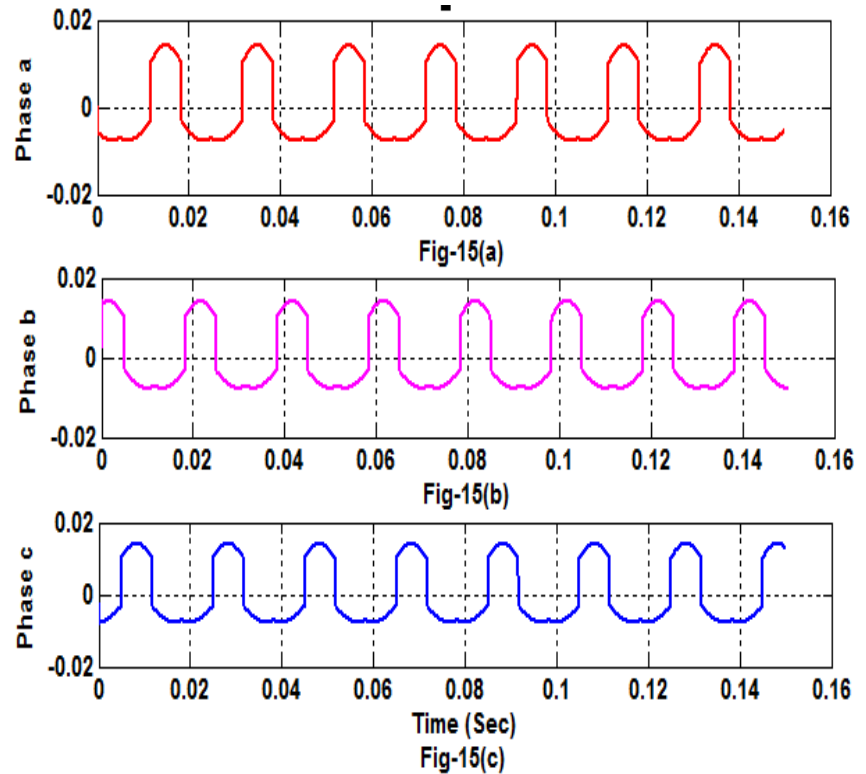

Fig-15(a), 15(b), 15(c): Inverter output Current without $L C L R$ Filter of phase $\mathbf{a}, \mathbf{b}$ and $\mathbf{c}$ respectively.

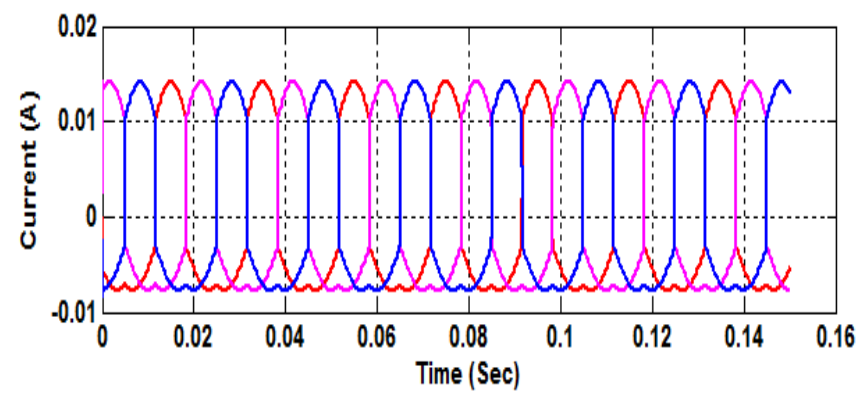

Fig-16: Inverter output Current without LCLR Filter of combined phases $\mathbf{a}, \mathbf{b}$ and $\mathbf{c}(\mathbf{0 . 0 1 5} \mathbf{A})$.

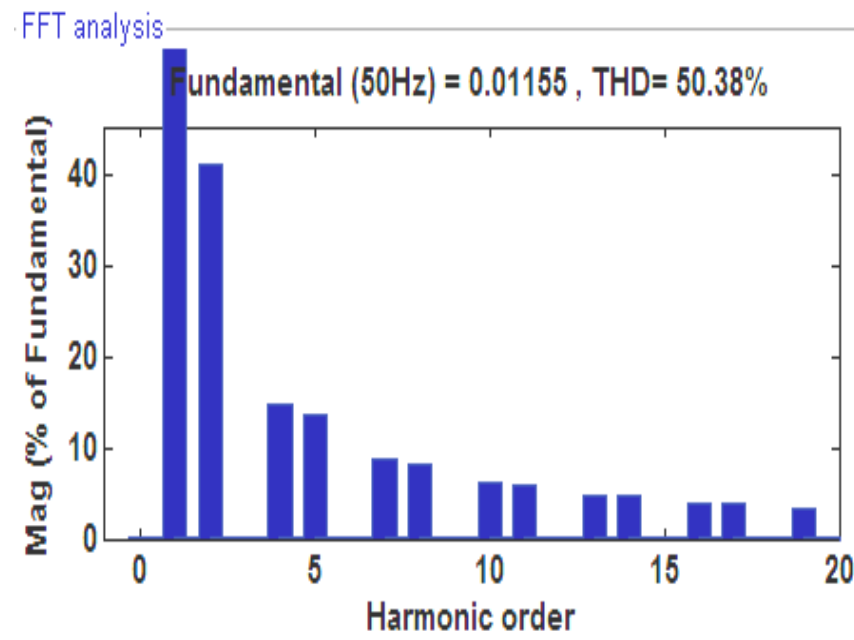

Fig-17: THD analysis of Inverter output Current without LCLR Filter.

\section{Inverter With LCLR Filter}

With the LCLR filter the THD of the system is reduced to very low level which improves the power quality.
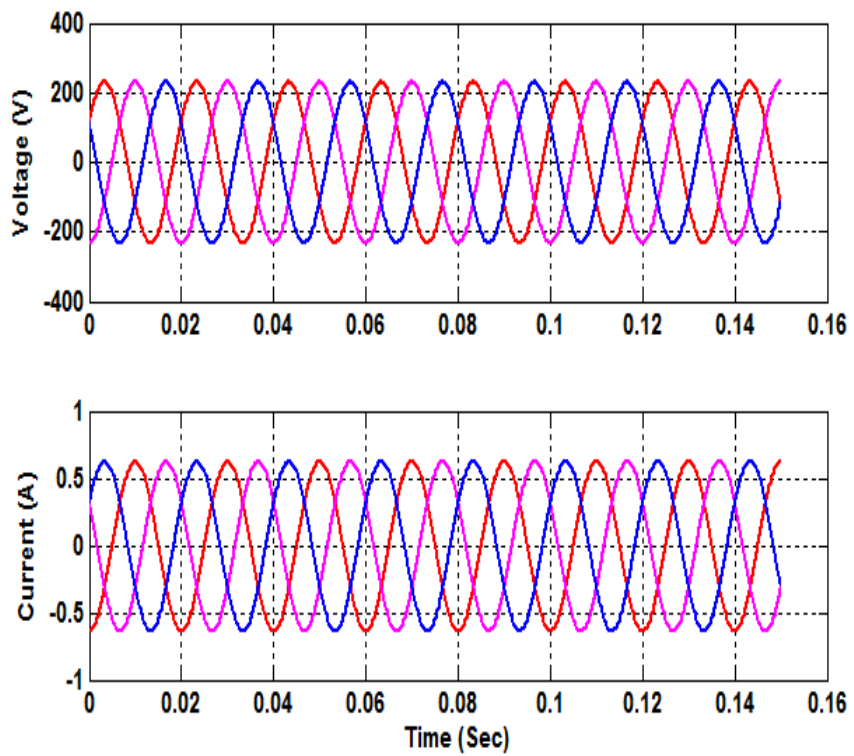

Fig-18: Inverter output active, reactive power, Voltage and Current with $L C L R$ Filter.

Fig-18 shows the inverter output voltage $(230 \mathrm{~V})$, current (0.6A); these quantities are nearly sinusoidal from the MATLAB simulation results. Means the total harmonic distortion percentage is almost reduced. Fig-19 shows the THD analysis of the current and THD of the system is only $0.94 \%$.

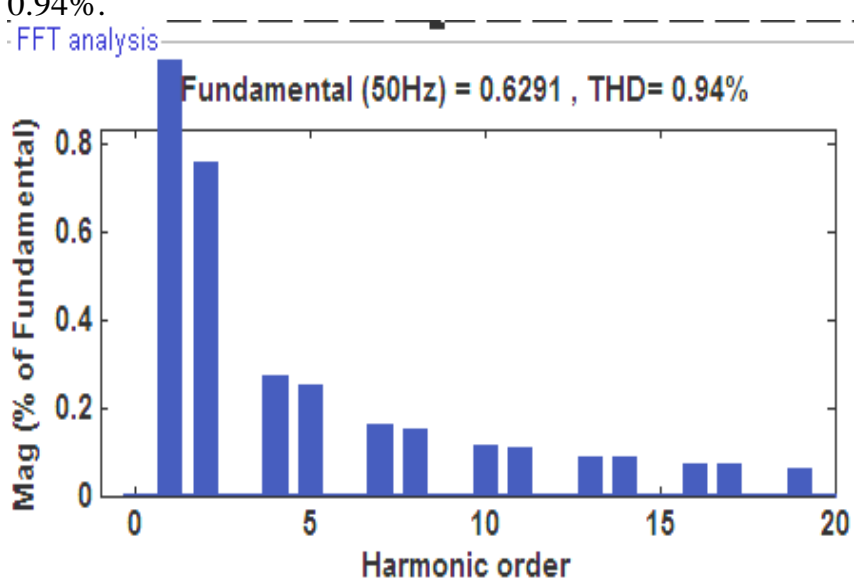

Fig-19: THD analysis of Inverter output current with $L C L R$ filter

\section{CONCLUSIONS}

In this paper LCLR filter is designed systematically with grid connected inverter system. The inverter is fed by renewable energy sources as PV cell and generates required DC voltage; these papers also proposes DC-DC Boost Converter for regulating the voltage of PV cell and boost the voltage level up to optimal required voltage for inverter. The very cheap $L C L R$ filter with grid connected inverter reduces system THD and it is found that proposed $L C L R$ filter meets THD within prescribed range which is up to $0.94 \%$ therefore power quality would be improved as well as grid interconnection of inverters with renewable energy sources is done bitterly. 


\section{ACKNOWLEDGEMENT}

I would like to thank Prof. C. L. Bhattar for his valuable guidance and support. I also thanks to Prof. A. R. Thorat Sir HOP and Prof. H.T. Jadhav HOD of Electrical department at Rajarambapu Institute of Technology, Sakhrale, Islampur for their guidance.

\section{REFERENCES}

[1]. Aleksandr Reznik, Marcelo Godoy Simoes, Ahmed Al-Durra and S. M. Muyeen, "LCL Filter Design and Performance Analysis for GridInterconnected Systems," IEEE Trans. Ind. Appl., vol.50, no.2, pp. 1225-1232 Mar/April. 2014

[2]. F. Bouchafaa, D. Beriber, and M. S. Boucherit, "Modeling and control of a grid connected PV generation system," in Proc. 18th MED Conf. Control Autom., 2010, pp. 315-320

[3]. Singh Bhim, Jayaprakash P, Somayajulu TR, Kothari DP. "Reduced rating VSC with a zig-zag transformer for current compensation in a three-phase four wire distribution system,', IEEE Trans Power Deliv 2009; 24 (1): 249.

[4]. Singh Bhim, Jayaprakash P, Kothari DP. "A Tconnected transformer and three leg VSC based DSTATCOM for power quality improvement," IEEE Trans Power Electron 2008; 23 (6):2710-8.

[5]. Zaveri Tejas, Bhalja Bhavesh, Zaveri Naimish. "Comparison of control strategies for DSTATCOM in three-phase, four-wire distribution system for power quality improvement under various source voltage and load conditions," Electr. Power Energy Syst 2012; 43: 582-94.

[6]. IEEE 1233 standard for power quality definitions.

[7]. IEEE 519 standard for harmonic control in electrical.

[8]. KHELIF Messa oud, M'RAOUI Abdelhamid, MALEK Ali. "Simulation optimization and performance analysis of an analog, easy to implement, perturb and observe MPPT technique to be used in a $1.5 \mathrm{KW} \mathrm{p}$ photovoltaic system," Centre de Development des Energies Renouvelables, CDER, 16340, Algiers, Algeria.

[9]. Sajib Chakraborty, Saila Ishrat Annie and M. A. Razzak. "Design of Single-Stage Buck and Boost Converters for Photovoltaic Inverter Applications," 3rd Inter. Conf. on Informatics, Electron \& Vision 2014.

[10]. http://www.scribd.com/doc/53012897/slva372b/access ed on July, 2013.

[11]. R. O. Caceres, I. Barbi, "A boost dc-ac converter: Analysis, design, and experimentation," IEEE Trans. Power Electron., vol. 14, no. 1, pp. 134--141, 1999

[12]. Ravish R. Singh, "Electrical Networks," Tata McGraw-Hill Publication, first edition, 2008.

[13]. V. H. Prasad, "Average current mode control of a voltage source inverter connected to the grid: Application to different filter cells," M.S. thesis, Dept. Elect. Eng., Virginia Polytech. Inst. State Univ., Blacksburg, VA, USA, 1997.
[14]. Y. Tang, S. Member, P. C. Loh, P. Wang, and F. H. Choo, "Generalized Design of High Performance Shunt Active Power Filter With Output LCL Filter," IEEE Transactions on Industrial Electronics, vol. 59, no. 3, pp. 1443-1452, 2012.

[15]. S. V. Araújo, A. Engler, B. Sahan, V. U. Kassel, F. Luiz, and M. Antunes, "LCL filter design for gridconnected NPC inverters in offshore wind turbines," in Proc. 7th Int. Conf. Power Electron., 2007, pp. 11331138.

[16]. M.G. Villalva, J.R. Gazoli, E. Ruppert "Modeling and Circuit Based Simulation of Photovoltaic Arrays", Brazilian Journal of Power Electronics, Vol. 14, No. 1, pp. 35-45, 2009.

[17]. C. Osorio. Matlab-Simulink models, Math works.

[18]. http://ecee.colorado.edu/ ecen2060/matlab.html.

\section{BIOGRAPHIES}

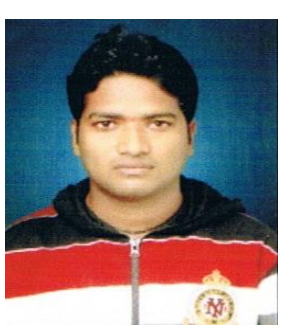

Dhananjay S. Sargar received the B.E degree in Electrical engineering from Annasaheb Dange College of Engineering and Technology Ashta, Sangli, Maharashtra, India in 2013. Currently he is pursuing M.Tech in Electrical (Power System) at Rajarambapu Institute of Technology, Sakhrale (Islampur), Maharashtra, India. His area of interest includes Power quality improvement and Renewable Energy sources.

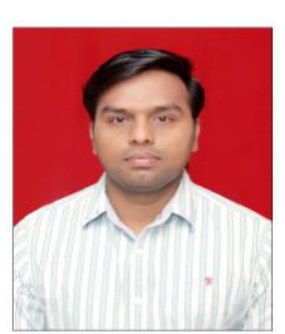

Chandrakant L. Bhattar received the B.E. degree in electrical engineering from Government College of Engineering, Karad, India, in 2008, and the M.Tech. Degree in electrical power system from Government College of Engineering, Amravati, India in $2011 \mathrm{He}$ is currently working as an Assistant Professor in Electrical Engineering Department, Rajarambapu Institute of Technology, Maharashtra, India. His research interests are Power Quality and Application of Power Electronics in Power System and Smart Grid. 